Jan Gustaw Rokita

(Warszawa)

https://orcid.org/0000-0002-1904-683X

\title{
XVII-WIECZNE MEDALE \\ ORAZ NUMIZMATY PAMIĄTKOWE POŚWIĘCONE OBLEZŻENIU OSMAŃSKIEMU WIEDNIA W 1683 ROKU I JEGO NIEKTÓRYM ASPEKTOM
}

\begin{abstract}
The chief aim of the paper is to introduce the reader to five specific pieces of medallic art, answer the questions what propaganda goals they were to accomplish, as well as provide am iconographic analysis, in comparison with selected examples of medals, graphic works, sculptures, and handicrafts.

\section{Keywords}

obverse, reverse, Sobieski, Vienna, Haffner

\section{STAN BADAŃ}

O medalach umożliwiających zapoznanie się współczesnym z oblężeniem tureckim 1683 roku i systemem obronnym Wiednia, stanowiących oficjalną papieską wykładnię wydarzeń rozgrywających się 12 września $1683 \mathrm{roku}^{1}$, napisano do dzisiaj bardzo niewiele. Podstawowe informacje na temat dzieł medalierskich Sobieskiego zawierają katalogi wystawowe: „Chwała i sława Jana III w sztuce i literaturze. Katalog wystawy jubileuszowej z okazji trzechsetlecia odsieczy wiedeńskiej”, „Rzeczpospolita w dobie Jana III. Katalog wystawy Zamku Królewskiego”, „Ar-

${ }^{1}$ Podstawowe informacje na temat odsieczy wiedeńskiej znajdzie czytelnik w pracach: Brouck, Leitsch, Vocelka, Wimmer, Wójcik 1983, Łoski 2019 oraz w artykułach popularnonaukowych: Nagielski 2019, Augustyniak 2019, Kołodziejczyk 2019, Kossarzecki 2019, s. 6-15, 18-25, 37-45, 67-79.
\end{abstract}


chiwum Głównego Akt Dawnych i Biblioteki Narodowej”, „Odsiecz Wiedeńska. Wystawa jubileuszowa w Zamku Królewskim na Wawelu w trzechsetlecie bitwy” oraz „Tron pamiątek ku czci Najjaśniejszego, Niezwyciężonego Jana Sobieskiego Króla Polskiego w trzechsetlecie śmierci 1696-1996”2.

Ikonografii Jana III Sobieskiego i jego najbliższej rodziny poświęcili swe prace m.in. Aleksander Czołowski, Magdalena Górska czy w końcu Hanna Widacka, autorka katalogu grafiki portretowej Jana III Sobieskiego pt. „Lew Lechistanu. Jan III Sobieski w grafice"s.

Autor artykułu przeprowadził analizę ikonograficzno-ikonologiczną sprowadzającą się do przedstawienia czytelnikowi materiału głównego, a więc konkretnego numizmatu, a następnie interpretacji materiałów pomocniczych w postaci wybranych dzieł grafiki i numizmatyki. Głównym celem jest wykazanie, że autorzy prac medalierskich, na których awersach i rewersach zostały odwzorowane konkretne epizody wojenne z batalii wiedeńskiej bądź też wygląd fortyfikacji Wiednia, projektując i tworząc własne prace, opierali się na wcześniejszych grafikach czy też przedstawieniach numizmatycznych powielanych za pośrednictwem licznych XVII-wiecznych kompendiów emblematycznych. Środkiem służącym do realizacji celu badawczego stały się, oprócz przykładów medalierstwa, grafiki i malarstwa opisanych w wymienionych wyżej katalogach, także katalogi zbiorów prywatnych domów aukcyjnych ${ }^{4}$. Okoliczności i szczegółowy przebieg wiktorii wiedeńskiej opisywałem już w poprzednich publikacjach, tutaj pozwolę więc sobie pominąć tę część wprowadzenia ${ }^{5}$.

\section{ANALIZA MEDALI}

Realizacji doniosłego celu dysponenta, jakim było bez wątpienia przybliżenie ówczesnemu odbiorcy (nie zawsze prawdziwych) informacji o przebiegu bitwy wiedeńskiej, odpowiadających wygórowanym ambicjom cesarskim, poświęcono medal autorstwa Hermana Haffnera z 1683 roku $^{6}$ (il. 1). Twórcy numizmatów zazwyczaj decydowali się na upamiętnienie na medalowym krążku jedynie starannie wybranych

${ }^{2}$ Chwała i sława Jana III 1983, Rzeczpospolita w dobie Jana III 1983, Odsiecz wiedeńska 1990, Tron pamiątek 1996.

${ }_{3}$ Czołowski 1930, s. 265-266, Ruszczycówna 1982, s. 209-307, Górska 2013, s. 66-90, Widacka 2010.

${ }^{4}$ Dostępne [online]: <www.acsearch.com>.

${ }^{5}$ Mowa o artykułach $\mathrm{z}$ lat 2014-2019 cytowanych w bibliografii.

${ }^{6}$ Kraków, Muzeum Narodowe (zbiory E. Hutten-Czapskiego), nr inw. VII-Md-490; Warszawa, Biblioteka Narodowa, Zakład Zbiorów Ikonograficznych, nr inw. I.G. 18289, I.G. 18291; Własność prywatna. Przedmiot wystawiony na aukcji antykwariatu numizmatycznego Fritz Rudolf Künker GmbH \& Co. KG (Osnabrück), 19 czerwca 2008 roku (aukcja 141, kat. 4595); Hess 1881-1883, poz. 913; Hirsch 1883, poz. 9, tab. I, il. 7; Hutten-Czapski 1871-1916, poz. 2947; Bartynowski, poz. I.G. 18285, I.G. 18291; Chwała i sława Jana III 1983, s. 225, kat. 209; Odsiecz wiedeńska 1990, I, s. 248, kat. 403. 

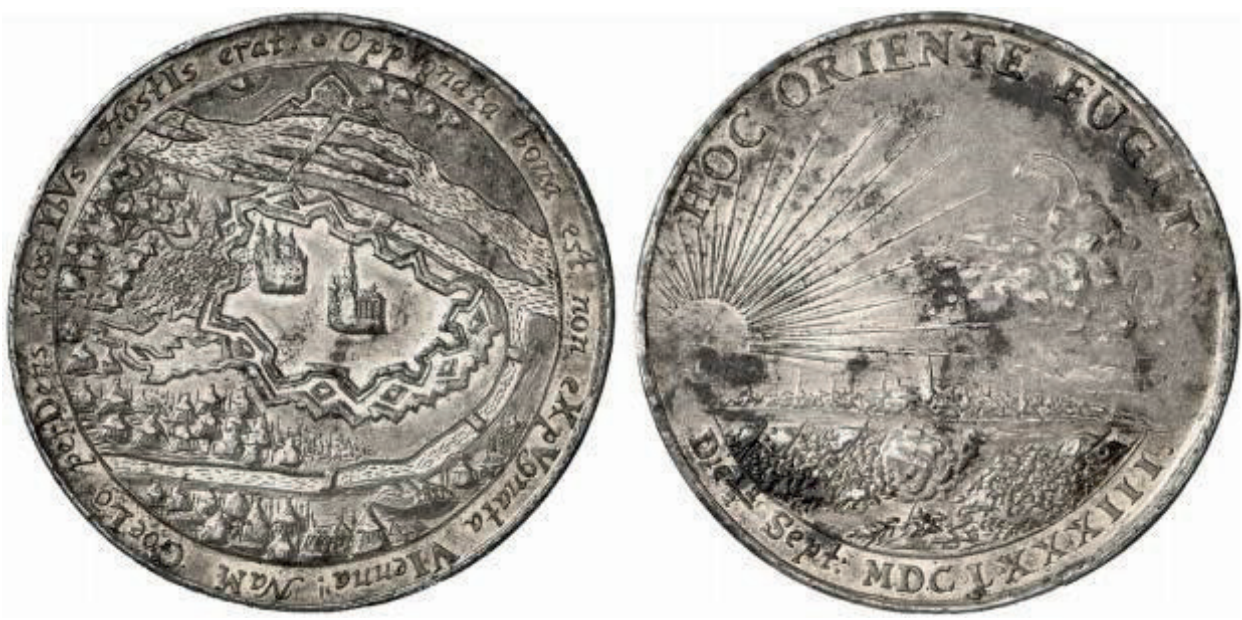

Il. 1. Medal pozwalający odbiorcy na zapoznanie się z zarysem ogólnym i położeniem umocnień miejskich, a także zabudowań cesarskiej stolicy podczas oblężenia tureckiego, emitowany z inicjatywy dysponenta cesarskiego, Herman Haffner, Wiedeń, 1683, srebro, śr. 43 mm, bity. Przedmiot wystawiony na aukcji antykwariatu numizmatycznego Fritz Rudolf Künker GmbH \& Co. KG (Osnabrück), 19 czerwca 2008 roku (aukcja 141, kat. 4595).

Źródło: [online]. ACSearch [dostęp: 2017-02-27]. Dostępny w Internecie: <http://www.acsearch.info/search.html?id $=492732>$.

scen, których selekcja uzasadniona była treścią inskrypcji. Powyższy wybór umożliwiał uchwycenie danego momentu historycznego na kompozycji awersu czy rewersu ze wszystkimi nieodzownymi szczegółami: uzbrojeniem obydwu walczących stron czy zbliżonym wyglądem teatru działań wojennych. Wartość edukacyjna takiego medalu była jednak w dużym stopniu ograniczona. Zupełnie inne problemy występują natomiast w przypadku dzieł medalierskich, które inspirowane były graficznymi wyobrażeniami pola bitewnego, widzianego z lotu ptaka. Mimo że odbiorca, studiując wspomnianą kompozycję, mógł zdobyć wiedzę na temat danego wydarzenia historycznego, ze względu na niewielkie rozmiary krążka, a także obiektywne trudności wynikające z niedoskonałości powszechnie obowiązujących technik medalierskich, wierna rekonstrukcja epizodów z przeszłości stawała się w praktyce niemożliwa. Wyżej opisany medal jest dobrym przykładem przeszkód utrudniających właściwą percepcję obrazu utrwalonego na medalu.

Plan oblężonego Wiednia wypełniający awers dzieła anonimowego medaliera będący zapewne powtórzeniem wcześniejszej ryciny przeniesiono na krążek medalu dokładnie, o czym świadczy chociażby precyzyjne odtworzenie murów miejskich $\mathrm{z}$ bastionami i rawelinami wraz z obiegającym je kanałem obronnym oraz umocnieniami Prateru i drugiego brzegu Dunaju? . Wewnątrz pierścienia for-

${ }^{7}$ Nowożytne fortyfikacje cesarskiej stolicy zlokalizowane na drugim brzegu Dunaju miały na celu uniemożliwienie przeciwnikowi prowadzenia ostrzału murów cesarskiej stolicy. Ostatecznie 
tyfikacji odwzorowano miniaturowe sylwetki katedry św. Szczepana oraz zamku Hofburg. Także i obóz turecki, założony w pobliżu fortyfikacji cesarskiej stolicy i podzielony na dwie części przez Wiedenkę z przerzuconymi nad nią trzema mostami, przedstawiono dość szczegółowo, również z rozmieszczeniem namiotów i artylerii. Napis otokowy awersu medalu: eXpVgnata VIenna: NaM CoeLo perDens HostIbVs HostIs errat (chronogram daty MDCLXXXIII) utwierdza czytelnika w przeświadczeniu, że ocalenie miasta należy przypisać interwencji Boga. Treść inskrypcji na krawędzi awersu medalu: CASVS IN OCCASV! PETE NUNQVAM TVRCA VIENNAM (Nie idź Turczynie na Wiedeń, na zachodzie zagłada) odnosi się natomiast do tureckiego przeciwnika. Dokładną datę odsieczy przypomniano z kolei w treści napisu u dołu rewersu: Die 12/2 Sept: MDCLXXXIII.

Niewątpliwie intencję autora medalu pragnącego przekonać odbiorcę, że europejska metropolia nie byłaby w stanie oprzeć się najeźdźcy tureckiemu bez zabezpieczeń w postaci murów i szeregu innych dodatkowych obiektów, należy uznać za w pełni uzasadnioną. Nowoczesny system fortyfikacji Wiednia przed 12 września 1683 roku sprawdzał się bardzo dobrze. Zasadnicze założenie powstało między 1637 a 1672 rokiem $^{8}$. Pierwsze jednak polowe umocnienia zaczęto budować jeszcze w latach 40. XVI wieku. W międzyczasie doszło do znaczących zmian w dziedzinie obronności. Tym samym w trakcie inwestycji nastąpiła konieczność korekty dotychczasowych planów. Ogółem wzniesiono 12 sześciokątnych bastionów skomunikowanych doskonale z kurtynami, bronionymi przez poprzedzające całość wały oraz wykopano fosy - szerokie na $20 \mathrm{~m}$ i głębokie na 7-8 m. Ponadto właściwe fortyfikacje uzupełniały dodatkowo raweliny, ostatnie punkty oporu przed wtargnięciem nieprzyjaciela do miasta, oraz zamaskowane w ziemi ganki, kaponiery, szkarpy, kontrszkarpy i drewniane palisady. Teren w bezpośrednim sąsiedztwie, nazywany glacis, zrównano z ziemią. Przed przybyciem podkomendnych Kara Mustafy w okolice stolicy austriackiej ewakuowano mieszkańców przedmieść potencjalnej bazy aprowizacyjnej dla wojsk tureckich.

Analizując zachowane plany obrazowe Wiednia, wykonane wkrótce po 12 września 1683 roku, na których uwzględniono również fortyfikacje stolicy austriackiej, trzeba wspomnieć o jednym (zachowanym w technice akwaforty) z 1683 roku, który można próbować porównywać do kompozycji awersu medalu. Jego autorem był Romeyn de Hooghe, wydawcą zaś Nicolas Visscher, działający w Amsterdamie 9 (il. 2). Autor nie poprzestał jedynie na rekonstrukcji fortyfikacji

jednak, w wyniku przewagi liczebnej strony tureckiej dysponującej ponadto silną artylerią, wspomniane umocnienia podczas oblężenia miasta nie spełniły planowanej przez obrońców roli.

${ }^{8}$ Sturminger 1951, s. 349-369; Stoye 2009, s. 23; Düriegl 1981, s. 23-34; Die erste Türkenbelagerung, s. 34-45; Die Türken vor Wien, s. 43-45.

9 Kraków, Muzeum Narodowe, Zbiory Czartoryskich, nr inw. R. 7472; Katalog der Ausstellung, s. 29-30, poz. 94, 95; Czołowski 1930, s. 1-56, poz. 27; Chowaniec 1933, s. 33, poz. 56; Katalog wysta- 


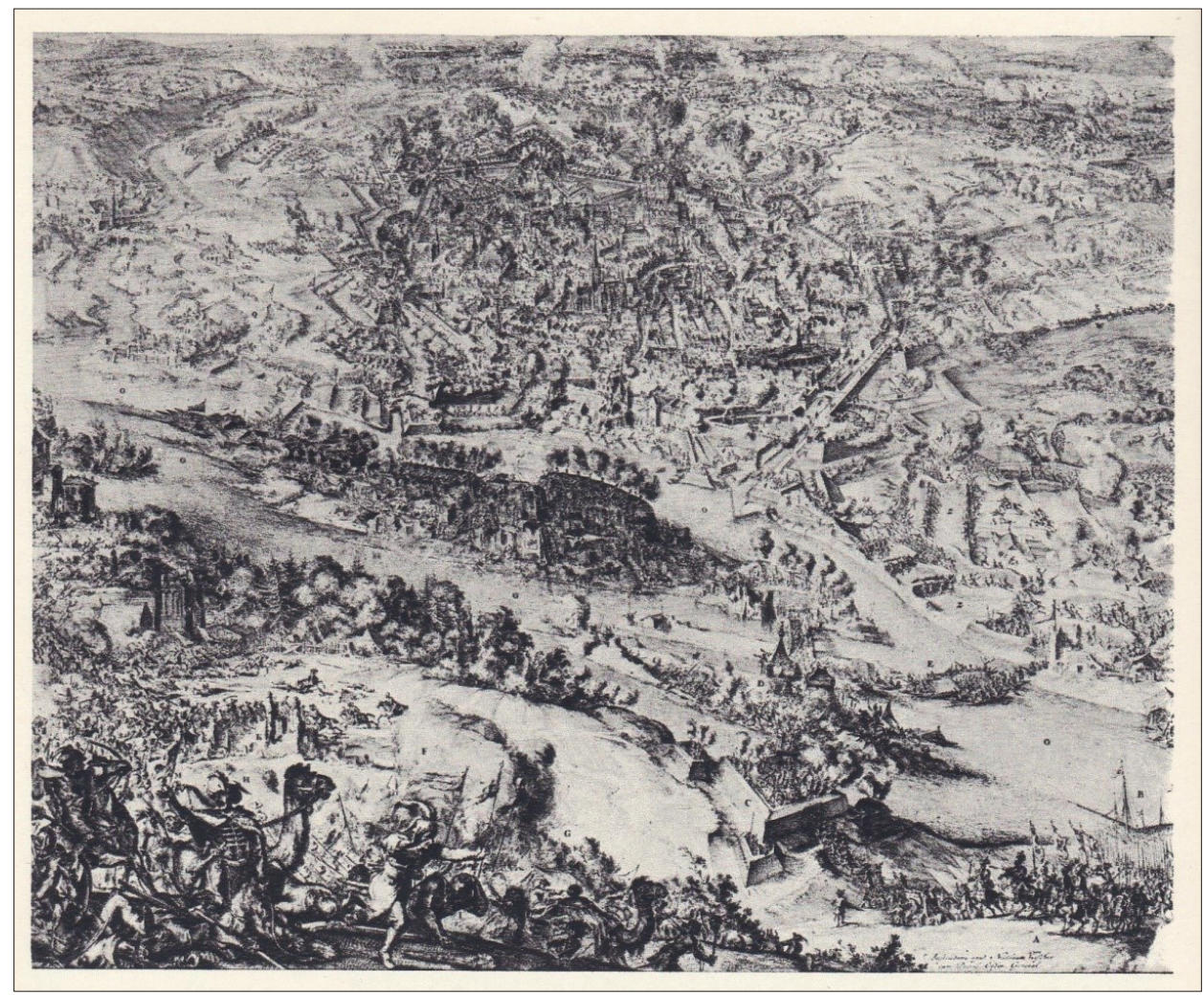

Il. 2. Plan widokowy oblężonego Wiednia, Romeyn de Hooghe (rytownik), Nicolas Visscher (wydawca), Amsterdam, 1683, akwaforta, wym. 45,8 x 57,2 cm (płyta), 71,2 x 57,2 cm (płyta wraz z tekstem), reprodukcja.

Źródło: Chwała i sława Jana III 1983, kat. 110, il. 28.

wiedeńskich $\mathrm{z}$ bastionami i rawelinami, widzianych $\mathrm{z}$ lotu ptaka na tle rozlewisk Dunaju, umocnionych pozycji wojsk tureckich na przedmieściu Leopoldstadt i robót oblężniczych ${ }^{10}$. Stosunkowo dokładnie wykreślono plan ulic i placów. Zabudowę w większości tworzą mniej lub bardziej okazałe kamienice mieszczańskie, pałace i kościoły z wieżami. W centrum dominuje masywna gotycka bryła katedry św. Szczepana ${ }^{11}$. Poniżej, wzdłuż drugiego brzegu rzeki, wznoszą się fortyfikacje bastionowe, zdobyte przez sprzymierzonych.

wy 1933, s. 143, poz. 310; Treiderowa 1960, s. 37; Landwehr 1973, s. 123; Chwała i sława Jana III 1983, kat. 110, il. 28; Rzeczpospolita w dobie Jana III 1983, s. 198, poz. 510, fig. 48.

${ }^{10} \mathrm{~W}$ legendzie w dolnej części planu znajdujemy szczegółowe objaśnienia najważniejszych budowli obronnych.

${ }^{11}$ Na rycinie de Hooghe na pierwszym planie wyeksponowano również dramatyczne sceny rozgrywające się w nieznacznej odległości od cesarskiej stolicy. W obrębie obozu tureckiego 
Można wyróżnić dwie przyczyny zastosowania przez twórców medalu i ryciny powyższego zabiegu artystycznego. Po pierwsze chodziło o udostępnienie rzetelnych danych dotyczących umocnień miasta obleganego przez Turków przez prawie dwa miesiące (od 14 lipca do 12 września 1683 roku). Nawet pobieżny kontakt $\mathrm{z}$ awersem medalu czy ryciną (miedziorytem) mógł dać odpowiedź na pytanie, dlaczego Wiedeń nie uległ przeważającym siłom imperium osmańskiego. Ponadto zakładając, że osoba, dla której przeznaczone były omawiane dzieło sztuki medalierskiej i rycina, miała styczność ze źródłami pisanymi informującymi o kampanii wiedeńskiej, istniała możliwość odnalezienia na kompozycji medalierskiej i graficznej miejsc opisanych przez ówczesnych świadków wydarzeń pod murami cesarskiej stolicy.

W odróżnieniu od pierwszej strony medalu, pełniącej głównie funkcje dydaktyczne, na rewersie zaprezentowano epizod wojenny znany już z wcześniejszych medali: natarcie kawalerii sojuszniczej w pełnym galopie i zwartym szyku na ewakuujących się tureckich „spahisów”. Zamierzeniem twórcy i dysponenta (zapewne cesarskiego?) było niewątpliwie ułatwienie odbiorcy, znającemu już szczegóły teatru działań wojennych, poznania przebiegu samych walk. Utrwalona za pośrednictwem kompozycji artystycznej scena ma również wymiar propagandowy. Klęska imperium osmańskiego jest przedstawiona także w dalszej części rewersu. Zachód muzułmańskiego księżyca wraz z towarzyszącym mu wschodem słońca chrześcijańskiego nie pozostawia wątpliwości co do jego interpretacji. Napis znajdujący się u góry: HOC ORIENTE FUGIT (Gdy ono wschodzi, księżyc zachodzi) można uznać za komentarz do wzmiankowanych zjawisk astronomicznych. Kolejna inskrypcja u dołu: Die 12/ 2 Sep[tembris] przypomina natomiast o dacie miesięcznej wiktorii wiedeńskiej.

Oddziałujące na siebie wzajemnie dwa ciała niebieskie stanowią również ważną część scenerii bitewnej. Niewykluczone, że medalierowi mogły być znane wcześniejsze numizmaty niekoniecznie związane z ikonografią batalistyczną, lecz inspirowane m.in. XVII-wiecznymi przedstawieniami malarskimi. Podobny moment przekroczenia górnego punktu tarczy słonecznej linii horyzontu uwzględniono na rewersie monety o wartości ècusa z czasów Ludwika XIV, datowanej na 1648 rok $^{12}$ (il. 3). Na pierwszym planie można dostrzec porośnięty gęsto drzewami

\footnotetext{
utrwalono wojska polskie prawego skrzydła, ścigające Turków uciekających w kierunku Wiedenki. W lewym dolnym rogu ukazano m.in. biegnącego Turka z uniesionymi rękami, wielbłądy oraz ciała poległych w pełnym umundurowaniu i uzbrojeniu. Upamiętniony obok, w pozycji stojącej, dostojnik turecki w turbanie, szacie orientalnej spiętej guzami z pętlicami oraz nakryciu wierzchnim podnosi rękę w stronę jeźdźca w nakryciu głowy z przypiętą kitą piór oraz z szablą w ręku zapewne jednego ze sprzymierzonych.

12 Własność prywatna. Przedmiot wystawiony na aukcji antykwariatu iNumis, 22 października 2010 roku (aukcja 13, kat. 2092).
} 


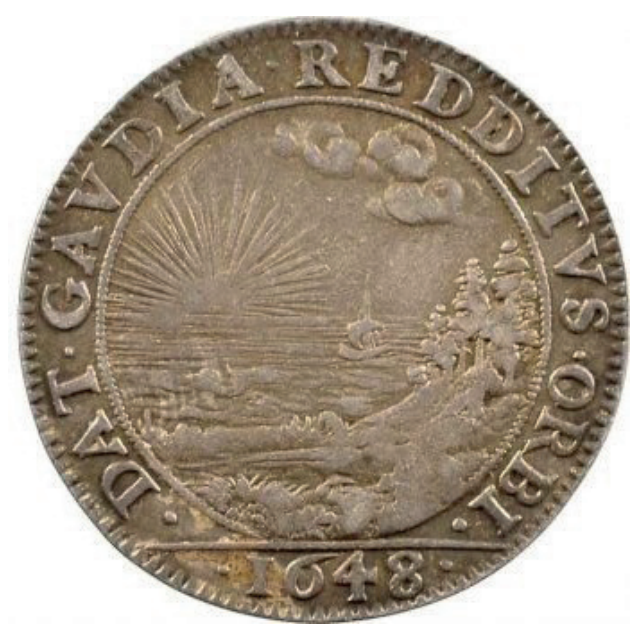

Il. 3. Moneta o wartości „ècusa” z czasów Ludwika XIV, z uwzględnionymi na rewersie wyobrażeniami: słońca rzucającego promienie oraz kłębów chmur po przeciwnej stronie, emitowany z inicjatywy rady królewskiej, nieznany pracownik mennicy, 1648, srebro, śr. 26,5 mm, bity. Przedmiot wystawiony na aukcji antykwariatu iNumis, 22 października 2010 roku (aukcja 13, kat. 2092).

Źródło: [online]. ACSearch [dostęp: 2017-02-27]. Dostępny w Internecie: <http://www.acsearch.info/search.ht$\mathrm{ml}$ ?id=872054.

oraz krzakami brzeg morza. W pobliżu na tafli wody utrzymuje się niewielki statek z jednym żaglem. Najbardziej godny uwagi fragment kompozycji zaplanowano w górnej części. Widoczne w oddali słońce rzucające promienie uwieczniono również $\mathrm{w}$ fazie wschodu. Po przeciwnej stronie natomiast powyżej pojawiają się kłęby chmur, za którymi schował się księżyc. Napis w otoku: DAT[a] GAVDIA REDDITVS ORBI[s] 1648 umożliwia odczytanie intencji dysponenta.

W tym samym 1683 roku powstał jeszcze jeden medal dający odpowiednie wyobrażenie na temat położenia Wiednia i jego systemu obronnego ${ }^{13}$ (il. 4).

${ }^{13}$ Kraków, Muzeum Narodowe (zbiory E. Hutten-Czapskiego), nr inw. VII-Md-491; Własność prywatna. Przedmiot wystawiony na aukcji antykwariatu numizmatycznego Gorny \& Mosch Giessener Münzhandlung (Monachium) 15 października 2008 roku (aukcja 172, kat. 6085); Hutten-Czapski 1871-1916, poz. 5287; Hess 1881-1883, poz. 914; Hirsch 1883, poz. 10, tab. I, il. 8; Odsiecz wiedeńska 1990, I, s. 248-249, kat. 404. Omawianą kompozycję w niezmienionym kształcie powtórzono na rewersie kolejnego medalu, nieznanego twórcy, z 1683 roku. Wspomniany obiekt powstał również jako pamiątka odsieczy wiedeńskiej. Awers natomiast był inspirowany całkowicie odmienną tematyką. Na ceglanym kominie, zapewne jednego z domostw (widoczny jedynie dach), uwieczniono gniazdo ptasie (żurawie?), nad którym pieczę sprawuje zapewne jedno z rodziców. Drugi ptak, sportretowany w bliskim sąsiedztwie, leci w tym samym kierunku. Ze względu na okoliczności powstania medalu i treść napisu w półkolu: UND NEHRDICH EHRLICH wydaje się, że medalier pragnął wykazać, że wiedeńczycy oblegani przez Turków przeszli zwycięsko próbę czasu. Ponadto na odwrocie możemy dostrzec na tym samym dachu również oryginalnie rozwiązany wiatrowskaz - figurkę chłopca stojącego na kuli, trzymającego odwrócony turecki półksiężyc, a także górne kondygnacje 

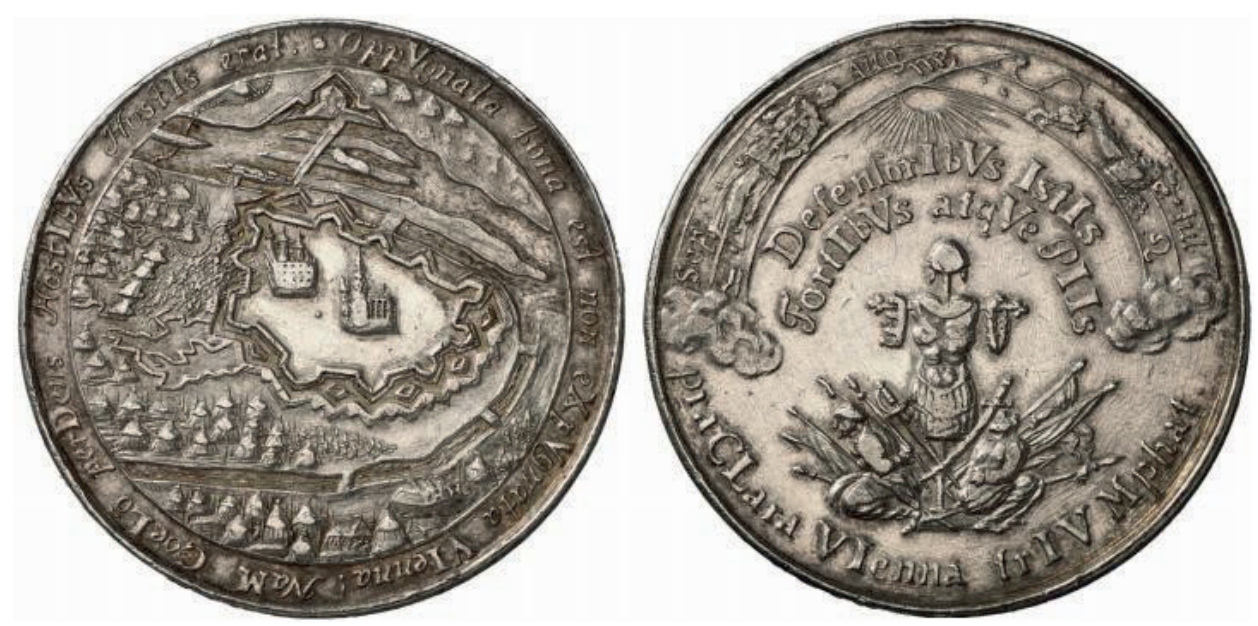

Il. 4. Medal wiedeński upamiętniający rzeczywisty wygląd fortyfikacji wiedeńskich (widzianych $\mathrm{z}$ lotu ptaka) oraz „tropajon” składający się z antycznego uzbrojenia, wybity na zlecenie dysponenta cesarskiego, Herman Haffner, 1683, srebro, śr. 44 mm, bity. Przedmiot wystawiony na aukcji antykwariatu numizmatycznego Gorny \& Mosch Giessener Münzhandlung (Monachium), 15 października 2008 roku (aukcja 172, kat. 6085).

Źródło: [online]. ACSearch [dostęp: 2017-02-27]. Dostępny w Internecie: <http://www.acsearch.info/search.html?id=527462>.

Medalier Herman Haffner dokonał powtórzenia (bez większych zmian) kompozycji awersu poprzedniego medalu, którą przeniósł na nowy krążek wraz z napisem otokowym. Rewers natomiast przywodzić miał na myśl popularne w drugiej połowie XVII wieku kompozycje graficzne i malarskie z panopliami skomponowanymi z różnego rodzaju broni antycznej i nowożytnej. W centrum odwzorowano tropajon - uzbrojenie naśladujące rzymski rynsztunek legionisty: płytowy pancerz, hełm oraz tzw. fartuszek z paskami cingulum, a także koronę aperta i wieniec laurowy (na ramionach wieszaka). Na ziemi leżą porzucone chorągwie nieprzyjacielskie, włócznie oraz skrzyżowane miecz i szpada. Para żołnierzy ze skrępowanymi rękami (jeńców tureckich), w orientalnych szatach i turbanach, siedzących po obu stronach omawianych łupów, może być uznana za najbardziej bezpośredni dowód zwycięstwa z 12 września 1683 roku. Podwójny napis w półkolu: DefensorIBVS IstIs FortIbVs atqVe PIIs dedykowano zapewne dysponentowi cesarskiemu. Inskrypcja (u dołu): pia CLara VIenna trIVMphat informuje o triumfie obrońców chrześcijaństwa. Elementem dodatkowym są znaki zodiaku (lwa i panny) oraz napisy z nazwami miesięcy: Sep[tember] - Aug[ust] - Iul[ii] odpowiadających okresowi oblężenia cesarskiej stolicy, umieszczone w górnej części, powyżej słoń-

innych budynków wzniesionych w pobliżu. Własność prywatna. Przedmiot wystawiony na aukcji antykwariatu Baldwin’s Auctions, 29 września 2009 roku, (aukcja 62-63, kat. 1401). 
ca rzucającego promienie na panoplia wojenne. Połączenie tematyki pogańskiej z chrześcijańską można usprawiedliwić szczytnym celem, jaki usiłowali osiągnąć zamawiający oraz medalier. Rok odsieczy wiedeńskiej zaszyfrowano w treści kolejnej inskrypcji u dołu: preClara Vienna trIVMphat, której litery tworzą chronogram 1683.

Do osobnej kategorii medali wiedeńskich należą numizmaty ufundowane z inicjatywy przywódcy Kościoła katolickiego. Papież z oczywistych powodów nie uczestniczył osobiście w działaniach wojennych pod Wiedniem, nie mógł również wysłać podległych sobie żołnierzy - gwardzistów szwajcarskich na pomoc oblężonym. Niemniej starał się wspomagać wiedeńczyków zarówno modlitwą, jak i propagandą.

Z działalnością dysponenta papieskiego podczas odsieczy wiedeńskiej związany jest zwłaszcza medal z 1683 roku, autorstwa Giovanniego Martino Hameraniego, służący uczczeniu zabiegów politycznych i dyplomatycznych Innocentego $\mathrm{XI}^{14}$ podejmowanych z zamiarem aktywizacji pozostałych mocarstw chrześcijańskich wobec zagrożenia tureckiego ${ }^{15}$ (il. 5). Mimo że przekaz wspomnianego dzieła sztuki medalierskiej nie dotyczy uczestników zmagań wojennych pod murami stolicy austriackiej, wypada go odnotować ze względu na przypisanie zwycięstwa wiedeńskiego interwencji ze strony Najwyższego w nieco odmienny sposób niż w przypadku medali wybitych na polecenie cesarskie.

Awers medalu wypełnia profilowane popiersie Innocentego XI w kapie pontyfikalnej z wyszytym po zewnętrznej stronie motywem roślinnym, spiętej pod szyją okrągłą zaponą oraz tiarze z dwoma dekoracyjnymi paskami (infulae). Inskrypcję otokową: INNOCEN[tius] XI x PONT[ifex] x MAX[imus] (Innocenty XI - Papież) zaopatrzono $\mathrm{w}$ aktualną tytulaturę. Znajdujący się na kompozycji rewersu

${ }^{14} \mathrm{~W}$ dniu 16 stycznia 1684 roku został uroczyście potwierdzony przez stronę polską dokument „La Lega Santa”, zgodnie z którym Leopold I, Innocenty XI i Jan III Sobieski zobowiązywali się do podjęcia walki z imperium osmańskim w imię wartości chrześcijańskich. Rzeczpospolitą podczas powyższej uroczystości reprezentował kardynał Carlo Barberini, por. Jaćov 2003, s. 180-195; Chynczewska-Hennel 2011, s. 54.

${ }_{15}$ Warszawa, Biblioteka Narodowa, Zakład Zbiorów Ikonograficznych, nr inw. I.G. 18468, I.G. 18469; Kraków, Muzeum Narodowe, nr inw. VII-MdP-813; Własność prywatna. Przedmiot wystawiony na aukcji antykwariatu numizmatycznego Jean Elsen \& ses Fils S.A, (Bruksela), 11 września 2010 roku (aukcja 106, kat. 1490); Ampach 1833-1835, poz. 6016; Hutten-Czapski 1871-1916, poz. 7728; Hirsch 1883, poz. 12, tab. II, il. 9; Polkowski 1884, s. 6-7; Lincoln 1898, poz. 1447, 1452; Bartynowski, poz. I.G. 18468, I.G. 18469; Manthey 1656, s. 13, 16-18, poz. 4, il. 4; Kamiński, Kowalczyk 1969, s. 121-136, poz. 81; Chwała i sława Jana III 1983, s. 227, kat. 213; Börner 1997, s. 1-458. Sygnaturę: HAMERANVS F.; sporządzono na awersie (w przecięciu ramienia królewskiego). Na egzemplarzu medalu znajdującym się w zbiorach Muzeum Narodowego w Krakowie umieszczono znaczek C informujący o przynależności numizmatu do kolekcji Emeryka Hutten Czapskiego. 

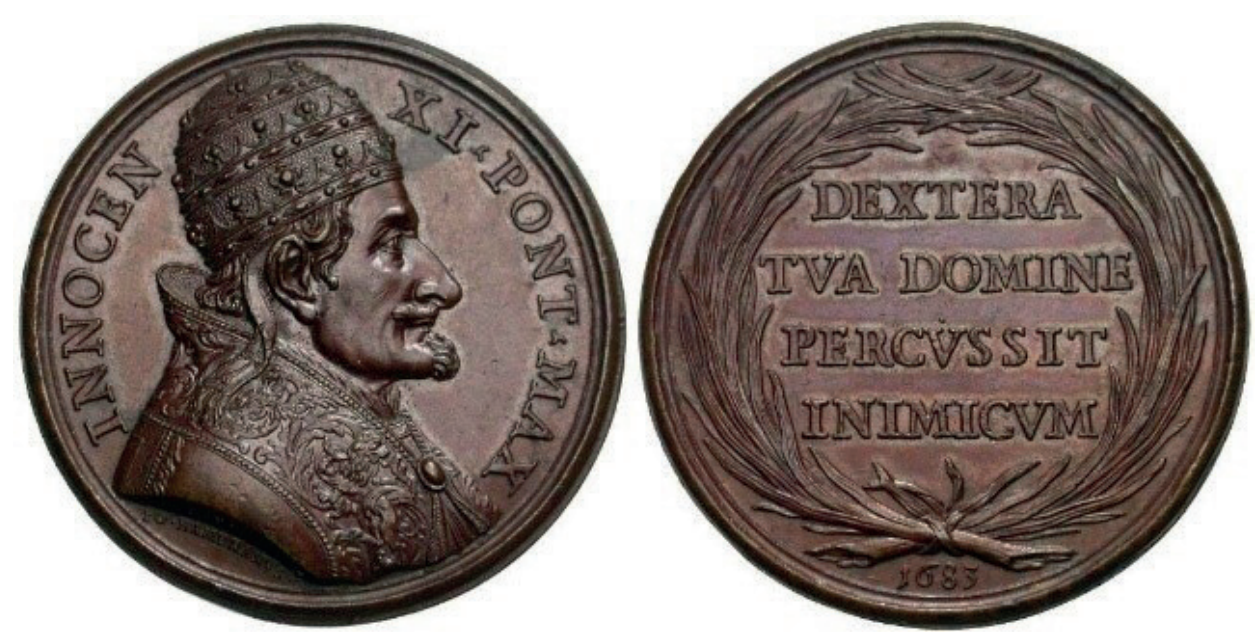

Il. 5. Medal podnoszący zasługi głowy Kościoła katolickiego podczas tureckiego oblężenia cesarskiej stolicy, zaopatrzony w podobiznę Innocentego XI, w stroju pontyfikalnym (na awersie) oraz wieniec z liści laurowych i napis: DEXTERA TVA DOMINE PERCUSSIT INIMICVM (na rewersie), emitowany z inicjatywy dysponenta papieskiego, Giovanni Martino Hamerani, Rzym, 1683, brąz (srebro), śr. $48 \mathrm{~mm}$, bity. Przedmiot wystawiony na aukcji antykwariatu numizmatycznego Jean Elsen \& ses Fils S.A (Bruksela), 11 września 2010 roku (aukcja 106, kat. 1490).

Źródło: [online]. ACSearch [dostęp: 2017-02-27]. Dostępny w Internecie: <http://www.acsearch.info/search.ht$\mathrm{ml}$ ?id $=835843>$.

napis w czterech rzędach, ujęty w wieniec z liści palmowych: DEXTERA TVA DOMINE PERCUSSIT INIMICVM (Prawica twoja Panie uderzyła wroga) ${ }^{16}$, sugeruje, że rzeczywistym twórcą odniesionej wiktorii jest Bóg, którego prawica ukarała wrogów wiary chrześcijańskiej ${ }^{17}$.

${ }^{16}$ Według Magdaleny Górskiej inskrypcja: „Dextera Domini percussit inimicum” zlokalizowana na szarfie obiegającej wyłaniającą się zza chmur rękę (obok skrzydlatego putta) osłanianą przez elementy uzbrojenia: nałokcic i zarękawie oraz ściskającą buławę hetmańską, stanowiąca część opracowania graficznego tezy Andrzeja Kazimierza Wacława Kuropatnickiego z 1682 roku nawiązuje do inskrypcji: DEXTERA/ TVA DOMINE/ PERCVSSIT/ INIMICVM na rewersie medalu autorstwa Hameraniego z 1684 roku. Związek z przytoczoną wyżej inskrypcją wykazują także inskrypcje: DEXTERA DOMINI FECIT VIRTVTEM na rewersie żetonu koronacyjnego Michała Korybuta Wiśniowieckiego, autorstwa Jana Höhna (Hoehna) mł. z 1669 roku oraz „Dextera Domini percussit inimicum” (Prawica Pańska pogromiła nieprzyjaciela) na obrazie „Bitwa pod Chocimiem”, autorstwa Andrzeja Stecha, datowanym na okres przed 1679 rokiem, por. Górska 2017, s. 99-100.

17 Omawiana kompozycja artystyczna była rozpowszechniana w XVII wieku również za pośrednictwem innych medali papieskich. Można wyróżnić zwłaszcza numizmat, którego rewers nie odbiega od wyobrażenia na odwrocie opisywanego medalu. Odmiennie natomiast prezentuje się jego awers. Pierwszą stronę monety o wartości piastra, wykonanej w 1684 roku, wypełnia wizerunek papieski. Innocenty XI przywdział jednak nie szaty pontyfikalne, a zwykły strój biskupi: pelerynkę, bogato zdobioną stułę i czapkę obszytą futerkiem zwaną camauro. Własność prywatna. Przedmiot wystawiony na aukcji antykwariatu iNumis, 12 marca 2013, (aukcja 20, kat. 1565); Muntoni 1972-1973, poz. III/8/28. 
Tę samą dewizę wewnątrz wieńca palmowego ze wstążką sporządzano również na innych medalach powstałych podczas pontyfikatu Innocentego XI. Mowa w tym miejscu o monecie o wartości piastry, której rewers stanowił oparcie dla medaliera bądź był jedynie późniejszym powtórzeniem dostatecznie spopularyzowanej wersji pierwotnej ${ }^{18}$ (il. 6). Brak dokładnej daty emisji uniemożliwia rozstrzygnięcie powyższej kwestii. Nie ma natomiast wątpliwości co do osoby dysponenta. Rozpoznanie zleceniodawcy ułatwia herb papieski umieszczony na awersie, składający się z tiary usytuowanej nad skrzyżowanymi kluczami Piotrowymi (w górnej części) oraz kartusza $\mathrm{z}$ herbem aktualnego biskupa Rzymu zawierającym wyobrażenia orła (w górnym polu), lwa (w środkowym polu) i sześciu kadzideł w nawiązaniu do męczeńskiej śmierci na krzyżu Jezusa Chrystusa (w dolnym polu), a także napis w półkolu: INNOCENTIVS XI PONT[ifex] MAX[imus].
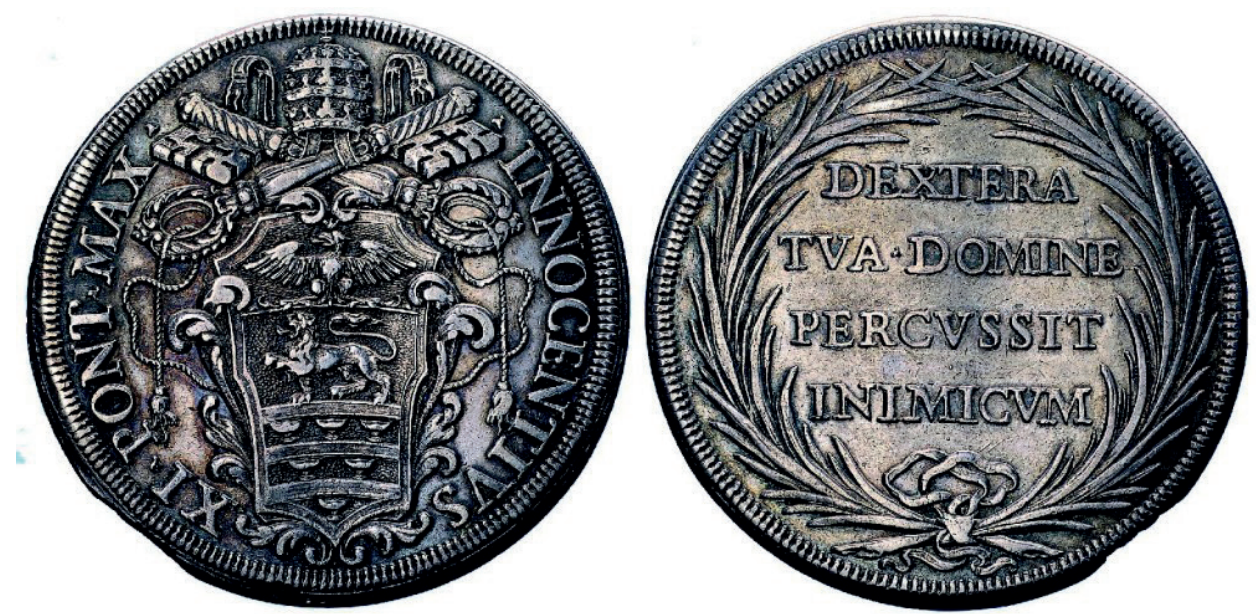

Il. 6. Moneta o wartości piastry Innocentego XI, którego najważniejszymi elementami kompozycji pozostają herb papieski (na awersie) oraz dewiza: DEXTERA TVA DOMINE PERCUSSIT INIMICVM (na rewersie), wybity na zlecenie dysponenta papieskiego, nieznany pracownik mennicy, brak daty, srebro, śr. (brak danych), bity. Przedmiot wystawiony na aukcji antykwariatu numizmatycznego Bolaffi (Turyn), 6 grudnia 2012 roku (aukcja 21, kat. 551).

Źródło: [online]. ACSearch [dostęp: 2017-02-27]. Dostępny w Internecie: <http://www.acsearch.info/search.ht$\operatorname{ml}$ ?id $=1457508>$.

Forsowana przez głowę Kościoła wizja zwycięstwa wiedeńskiego była akceptowana nie tylko przez Leopolda I, lecz również głównego współautora odsieczy wiedeńskiej - Jana III Sobieskiego. W liście napisanym w Wiedniu

18 Własność prywatna. Przedmiot wystawiony na aukcji antykwariatu numizmatycznego Bolaffi (Turyn), 6 grudnia 2012 roku (aukcja 21, kat. 551). 
13 września 1683 roku i wysłanym do stolicy Państwa Kościelnego za pośrednictwem Tomasza Talentiego, sekretarza królewskiego, i Jana Denhoffa, opata mogilskiego, wraz z jedną z chorągwi, mylnie kojarzoną z wielką chorągwią proroka, Sobieski pozytywnie ustosunkował się do postulatów propagandy papieskiej. Warto przytoczyć zwłaszcza początek tekstu listu gdyż odzwierciedla on propagandowy kontekst medalu $\mathrm{z}$ tego samego roku: „Venimus, vidimus, Deus vicit"19.

Motyw opieki ze strony Najwyższego podczas oblężenia austriackiej stolicy zdominował również przekaz medalu autorstwa Michaela Hofmana z 1683 roku $^{20}$ (il. 7). W centrum awersu można zauważyć wpisane w trójkąt oko Opatrzności ${ }^{21}$ promieniujące $\mathrm{w}$ kierunku dwugłowego, ukoronowanego orła cesarskiego $\mathrm{z}$ berłem i mieczem w szponach, podtrzymującego sercowate kartusze $\mathrm{z}$ herbami

${ }^{19}$ Geneza wspomnianego cytatu sięga czasów schyłku rzymskiej republiki i początków cesarstwa. Juliusz Cezar, relacjonując w korespondencji z senatem przebieg bitwy pod Zelą ( 2 sierpnia 47 roku p.n.e.), za pomocą podobnego zabiegu literackiego przypisał sobie autorstwo wiktorii odniesionej nad królem Farnacesem II: „Veni, vidi, vici”. Tablicę z wypisanymi trzema cytowanymi łacińskimi słowami pokazywano podczas pochodu triumfalnego zorganizowanego wkrótce po powrocie dyktatora do stolicy imperium. Podobne słowa miał w epoce nowożytnej wypowiedzieć cesarz Karol V zwyciężający pod Mulhdorf, 24 kwietnia 1547 roku, elektora Jana Fryderyka. Słowa te przypisał cesarzowi Johann Peter Lange, autor łacińskiego zbioru „Democritus ridens: sive campus recreationum honestarum cum exorcismo melancholiae" wydanego w 1655 roku w Amsterdamie, por. Ursyn-Niemcewicz 1830, s. 222; Górska, Milewska-Waźbińska 2010, s. 113. Więcej szczegółów na temat korespondencji Jana III Sobieskiego pisanej podczas kampanii wiedeńskiej znajdzie czytelnik w pracy Venimus 1984.

${ }^{20}$ Kraków, Muzeum Narodowe (zbiory E. Hutten-Czapskiego), nr inw. VII-Md-511; Warszawa, Muzeum Narodowe, nr inw. 16470 NPO; Biblioteka Narodowa, Zakład Zbiorów Ikonograficznych, nr inw. I.G. 18287; Własność prywatna. Przedmiot wystawiony na aukcji antykwariatu Auktionshaus H.D. Rauch GmbH (Wiedeń), 19 kwietnia 2016, (aukcja 101, kat. 1907); Hutten-Czapski 1871-1916, poz. 7745; Bartynowski, poz. I.G. 18287, I.G. 18288, I.G. 18290; Kamiński, Kowalczyk 1969, s. 121136, poz. 84; Chwała i sława Jana III 1983, s. 224-225, kat. 208; Odsiecz wiedeńska 1990, I, s. 252, kat. 415; Stahr 2008, s. 91, poz. 92. Inicjały MM zauważalne pomiędzy tarczami z herbami Swiętego Cesarstwa Rzymskiego i Wiednia należy odczytywać jako pierwsze litery imienia i nazwiska Matthiasa Mitermeyera a Waffenberga.

${ }^{21}$ Piramidalny kształt promieniującego nad miastem oka Opatrzności należy powiązać z symboliką solarną. Zgodnie $\mathrm{z}$ wierzeniami starożytnych Egipcjan grobowce faraonów ze względu na przyjętą formę przestrzennego trójkąta wyznaczały bieg promieni słonecznych. Powyższe podobieństwa determinował również układ wnętrz samych budowli: zbiegające się w jednym punkcie ściany oraz nachylone do wewnątrz korytarze. Epoka renesansu przyczyniła się do wzrostu zainteresowania spuścizną kulturalną po dawnych cywilizacjach Bilskiego Wschodu. Opisywane na kartach pamiętników i diariuszy wrażenia z podróży podejmowanych przez ówcześnie żyjących ludzi oraz pamiątki przywożone $\mathrm{z}$ odległych krain stały się bez wątpienia źródłem inspiracji również dla nowożytnych twórców okolicznościowych emblematów, por. Tervarent 1958, s. 282-283; Białostocki 1962, s. XXXVII; Chevalier, Gheerbrant 1996, s. 631. 

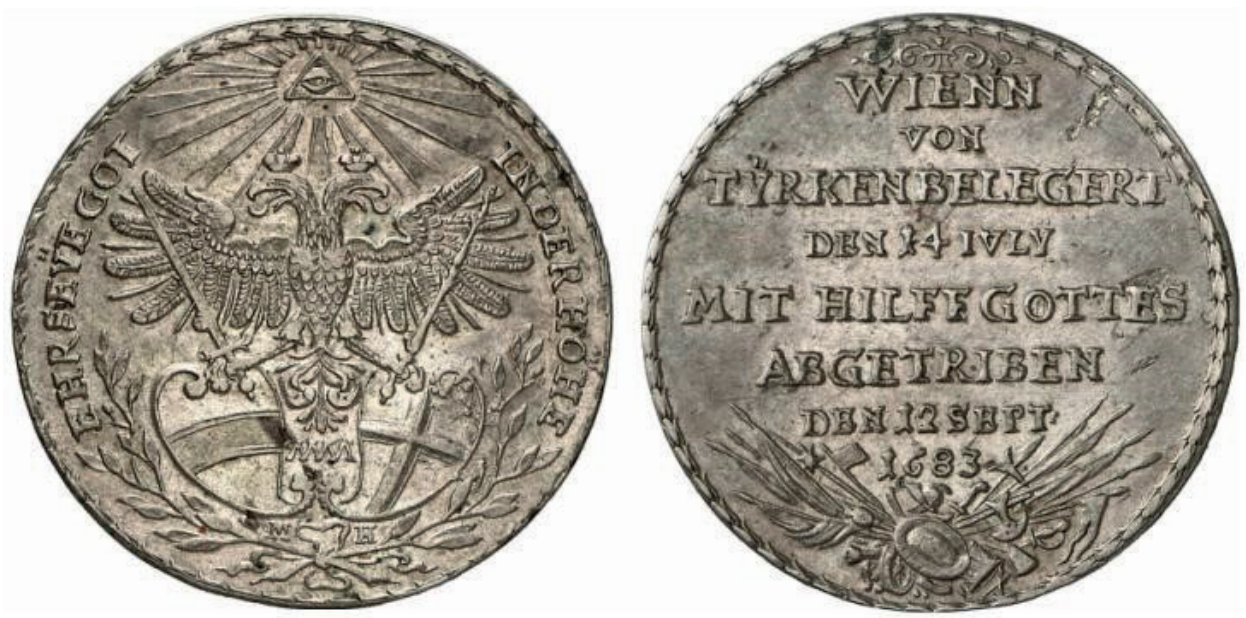

Il. 7. Medal, w którego przekazie przypisano oswobodzenie Wiednia bezpośredniej pomocy Bożej Opatrzności przedstawionej pod postacią oka promieniującego na dwugłowego orła z berłem i mieczem w szponach, podtrzymującego tarcze herbowe Austrii i Wiednia, wybity na zlecenie dysponenta zagranicznego (cesarskiego?), Michael Hofman, 1683, srebro, śr. 28 mm, bity. Przedmiot wystawiony na aukcji antykwariatu Auktionshaus H.D. Rauch GmbH (Wiedeń), 19 kwietnia 2016 (aukcja 101, kat. 1907).

Źródło: [online]. ACSearch [dostęp: 2017-02-27]. Dostępny w Internecie: <https://www.acsearch.info/search. html?id=3035436>.

Austrii i Wiednia ${ }^{22}$. Uwzględnione w dolnej części awersu dwie gałązki oliwne związane wstążką również wyrażają odrębne treści pacyfistyczne.

Rolę komentarza do kompozycji na awersie medalu pełni następująca inskrypcja: EHR SEŸE GOT IN DER HÖHE (Możliwe dzięki interwencji Boga). Treść napisu wskazuje, że trudna sytuacja mieszkańców miasta w trakcie oblężenia nie była Najwyższemu obojętna. Napis ośmiowierszowy na rewersie: WIENN VON TVRKEN BELEGERT DEN 14 IVLY MIT HILFF GOTTES ABGETRIBEN DEN 12 SEPT[ember] 1683 (Wiedeń oblężony przez Turków od 14 lipca oswobodzony z Bożą pomocą 12 września) informuje o okresie oblężenia. Największą korzyścią wynikającą z pokonania przeciwnika będzie zgodnie z symboliką gałązki z drzewa oliwkowego nastanie pokoju. Poniżej inskrypcji odwzorowano ponadto panoplia i sprzęt wojenny, m.in. owalną tarczę, szable, hełm, topór, maczugę, chorągwie, włócznię i armatę polową.

Oko stanowi ilustrację idei Boskiej Opatrzności. Problematyka wpływu Boga na losy jednostki podjęta została po raz pierwszy przez Augustyna z Hippony po-

${ }^{22}$ Wyobrażenia ukoronowanego dwugłowego orła dzierżącego w szponach miecz i berło można spotkać nie tylko na okolicznościowych rycinach, medalach czy obrazach, lecz również w dekoracji chorągwi cesarskich formacji wojskowych. Mowa w tym miejscu zwłaszcza o proporcu kawalerii cesarskiej należącym do zbiorów muzeum cieszyńskiego, na którym odnajdujemy analogiczną podobiznę najszlachetniejszego z ptaków oznaczającego nie tylko potęgę militarną Świętego Cesarstwa Rzymskiego, lecz również majestat władzy cesarskiej, por. Karger 1933, s. 200. 
wołującego się w pracy „De Civitate Dei” na poglądy głosicieli filozofii Platona dopuszczających teoretyczną możliwość istnienia jednego Boga, którego jednak kult miał być w starożytnej Helladzie niewystarczający ${ }^{23}$. Definicję Opatrzności bardziej szczegółowo wyłożył Tomasz z Akwinu w pierwszej części dzieła „Summa Theologica”. Wspomniany filozof chrześcijański przyznawał, że światem kieruje niewidzialna, lecz przewidywalna siła, znająca przyszłość każdego człowieka (Bóg), wobec której należało zachowywać szacunek ${ }^{24}$. Podstawą wszelkich rozważań teoretycznych były natomiast odpowiednio dobrane fragmenty Pisma Świętego Starego i Nowego Testamentu: Dziejów Apostolskich (Dz 24,2-3), Księgi Mądrości (Mdr 14,3, 17,2), Ewangelii św. Mateusza (Mt 6,25, 10,29-31) czy Listów Apostolskich św. Pawła (Rz 8,28).

Dużo starsza jest tradycja występowania oka Opatrzności w ikonografii. Narząd wzroku kojarzono w starożytnym Egipcie z bogiem Horusem, do którego przywiązanie manifestowano, nosząc amulety (wedjat) ${ }^{25}$. Twórcy chrześcijańscy mniej lub bardziej bezpośrednio nawiązywali w swych pracach do cytatu z Księgi Przysłów (Prz 15,3): „Na każdym miejscu są oczy Pańskie, dobrych i złych wypatrują". Powyższe wyobrażenie umieszczano nie tylko na elewacjach świątyń, lecz również m.in. portalach wejściowych prowadzących do wnętrza budynków użyteczności publicznej: ratuszy, giełd, domów kupieckich czy nawet prywatnych kamienic patrycjuszowskich. Nim przedstawienie oka Opatrzności zaadoptowali wolnomularze na potrzeby ukazującego się od 14 września 1797 roku z inicjatywy Thomasa Smitha Webba periodyku „The Freemason's Monitor, or Illustrations of Masonry" ${ }^{26}$, należało ono do najbardziej rozpowszechnionych symboli Trójcy Świętej pojawiających się w programie dekoracyjnym wznoszonych w dobie kontrreformacji świątyń. Hierarchowie katoliccy, zlecając artystom wykonywanie podobizn oka Opatrzności, powoływali się na dogmat o Trójcy Świętej, uchwalony podczas soboru konstantynopolitańskiego I (obradującego od maja do 30 czerwca 381 roku) i potwierdzony następnie przez cesarza Teodozjusza, 30 lipca 381 roku, a także na późniejsze ustalenia soboru w Nicei (trwającego od 20 maja do 19 czerwca $325 \mathrm{roku}$ ), tj. dogmat o wspólności natury Ojca i Syna.

Zagadnienie Bożej Opatrzności nie było obce również XVII-wiecznym medalierom. Przegląd zachowanych dzieł sztuki należy rozpocząć od rewersu monety o wartości czterech dukatów, której powstanie zbiegło się z koronacją Leopolda I na władcę Świętego Cesarstwa Rzymskiego 18 lipca 1658 roku $^{27}$ (il. 8). Mimo że

23 Ratzinger 1954; Gustave 1955, s. 430; Horn 1997.

24 Berger 2004; McGin 2014.

25 Barnett 1998, s. 43.

26 Pierwszy raz powyższe wyobrażenie w kontekście problematyki masońskiej powielono na stronie tytułowej periodyku Tomasa Weba „Freemasons monitora”, por. Hieronimus 1989.

27 Własność prywatna. Przedmiot wystawiony na aukcji antykwariatu numizmatycznego Gorny \& Mosch Giessener Münzhandlung (Monachium), 18 marca 2008 roku (aukcja 166, kat. 3730); 


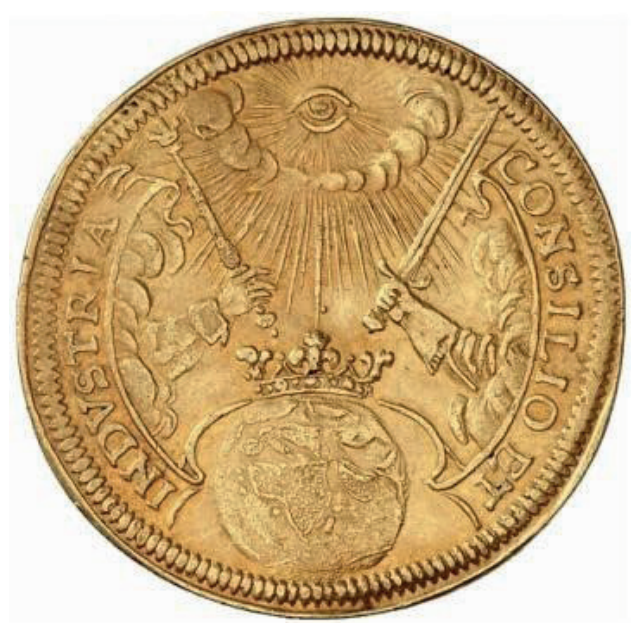

Il. 8. Moneta o wartości czterech dukatów, której powstanie należy wiązać z koronacją Leopolda I na cesarza niemieckiego we Frankfurcie nad Menem, nieznany pracownik mennicy cesarskiej, Austria, Węgry, 1658, złoto (srebro), śr. $28 \mathrm{~mm}$, bita. Przedmiot wystawiony na aukcji antykwariatu numizmatycznego Gorny \& Mosch Giessener Münzhandlung (Monachium), 18 marca 2008 roku (aukcja 166, kat. 3730).

Źródło: [online]. ACSearch [dostęp: 2017-02-27]. Dostępny w Internecie: <http://www.acsearch.info/search.ht$\mathrm{ml} ? \mathrm{id}=450694>$.

koncepcji zrealizowanej w mennicy cesarskiej nie można porównywać do wizji medaliera zajmującego się w późniejszym okresie godnym uświetnieniem wiktorii wiedeńskiej, wszystkie atrybuty i symbole oddano bez zmian. Insygnia koronacyjne: miecz i berło znajdują się jednak nie w szponach orła, a ściskane są przez dwie ręce wyłaniające się zza chmur. Korona, pierwotnie zdobiąca głowę zwierzęcia, spoczywa na globusie (w dolnej części). Nad całością góruje oko Opatrzności rzucające płomienie na przedmioty uwiarygadniające prerogatywy panującego. Napis otokowy: CONISILIO ET INDUSTRIA dotyczący osoby Leopolda I, powtórzono na rewersach medali powstałych w późniejszym okresie, m.in. na drugiej stronie dzieła medalierskiego Johanna Neidhardta wybitego w 1683 roku na cześć obrońców Wiednia.

Hess 1881-1883, poz. 872; Joseph, Fellner 1896-1920, poz. 495; Förschner 1992, poz. 83. Na 1658 rok datowany jest również medal związany z osobą Leopolda I Habsburga. Przedstawienie na rewersie wspomnianego numizmatu przeznaczonego w przeciwieństwie do funkcjonującej w powszechnym obiegu monety jedynie dla wybranych grup odbiorców stanowi częściowo skorygowaną wersję poprzedniej kompozycji artystycznej. Zamiast korony aperta na globie ziemskim leży korona clausa. Natomiast dłonie dzierżące pozostałe akcesoria koronacyjne: miecz i berło uwieczniono nie nad cesarskim nakryciem głowy, lecz po jego obydwu stronach. Reszta szczegółów, podobnie jak inskrypcja, są niezmienione. Własność prywatna. Przedmiot wystawiony na aukcji antykwariatu Gorny \& Mosch Giessen Münzhandlung (Monachium), 7 marca 2013 roku, (aukcja 213, kat. 4060). 
Na drugim z numizmatów przybliżono szerokim rzeszom odbiorców jeszcze jeden dowód na pomoc udzieloną osobiście przez Najwyższego podczas zmagań wojennych pod Wiedniem. Dzieło wyemitowane w 1683 roku zawdzięczamy nieznanemu medalierowi ${ }^{28}$ (il. 9). Nad zrekonstruowaną bardzo dokładnie panoramą metropolii unoszą się oko Opatrzności oraz trzy nieokreślone wyobrażenia w kształcie łez, stanowiące być może aluzję do Trójcy Świętej. Obydwie podobizny promieniują na najbliższą okolicę. Doniosłą konsekwencją nadprzyrodzonego zjawiska staje się ukazana w dolnej części krążka ucieczka Turków (pieszo lub konno) z pola bitwy i natarcie kawalerii cesarskiej dosięgającej nieprzyjaciela. Na pierwszym planie widać centralno-wieloboczny i dużo mniejszy prostokątny namiot turecki oraz ziemne umocnienia. Napis w otoku: DIE STADT SO GOTT BEVACHT ZERSTORT KEIN FINDES MACHT powinien być uważany za oficjalną wykładnię wydarzeń na przedpolach Wiednia.

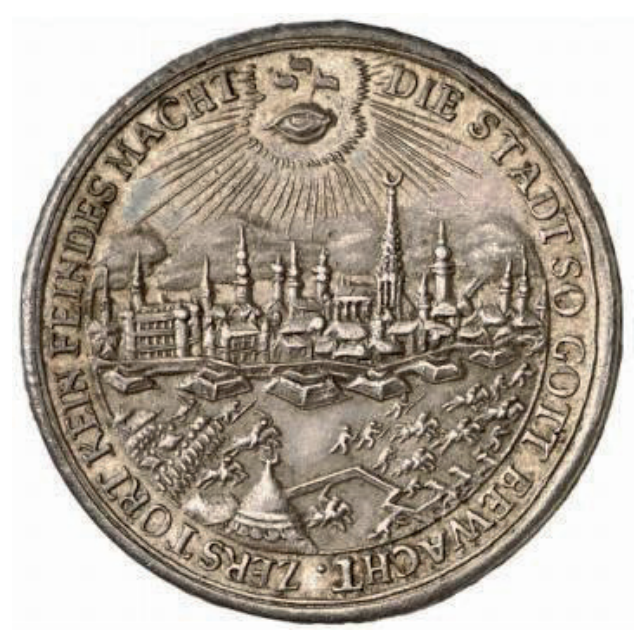

Il. 9. Medal, za pośrednictwem, którego przybliżono odbiorcy koncepcję osobistej interwencji Najwyższego podczas zmagań wojennych pod Wiedniem, emitowany z inicjatywy dysponenta cesarskiego, nieznany medalier, 1683, srebro, śr. $30 \mathrm{~mm}$, bity. Przedmiot wystawiony na aukcji antykwariatu numizmatycznego Gorny \& Mosch Giessener Münzhandlung (Monachium), 15 października 2008 roku (aukcja 172, kat. 6102).

Źródło: [online]. ACSearch [dostęp: 2017-02-27]. Dostępny w Internecie: <http://www.acsearch.info/search. html?id=527476>.

${ }^{28}$ Kraków, Muzeum Narodowe (zbiory E. Hutten-Czapskiego), inw. VII-MdP-505; Własność prywatna. Przedmiot wystawiony na aukcji antykwariatu numizmatycznego Gorny \& Mosch Giessener Münzhandlung (Monachium), 15 października 2008 roku (aukcja 172, kat. 6102); Hutten-Czapski 1871-1916, poz. 10 389; Hess 1881-1883, poz. 917; Hirsch 1883, poz. 63, tab. VI, il. 48; Odsiecz wiedeńska 1990, I, s. 248, kat. 401. 
Niewątpliwie analizowane medale z jednej strony służyły odbiorcy jako źródło podstawowej informacji na temat niedawnych wydarzeń historycznych, z drugiej zaś miały przyczyniać się do propagowania interpretacji wyniku rozgrywek militarnych pod Wiedniem, bliskiej zarówno dworowi cesarskiemu, jak i papieskiemu. Dla przykładu wypada przypomnieć medal autorstwa Michaela Hofmana z 1683 roku, na którego awersie uwzględniono podobiznę dwugłowego, ukoronowanego orła cesarskiego dzierżącego w szponach miecz, berło i sercowate kartusze z herbami Austrii i Wiednia, i opromienionego przez wpisane w trójkąt oko opatrzności, opatrzoną inskrypcją: EHR SEŸE GOT IN DER HÖHE. Na drugiej stronie innego medalu sporządzonego przez Giovanniego Hameraniego, ufundowanego zaś sumptem Innocentego XI w 1683 roku, oglądający dostrzeże jedynie napis: DEXTERA TVA DOMINE PERCUSSIT INIMICVM ujęty w wieniec palmowy. Odpowiadając na pytanie o powody determinujące określony wygląd powyższych kompozycji, należy zauważyć, że w sytuacji, kiedy zwłaszcza panujący w Wiedniu nie mógł pochwalić się osobistymi sukcesami odniesionymi na polu bitewnym w trakcie oblężenia stolicy austriackiej, szczególnie pożądane stawało się przypisanie szczęśliwego oswobodzenia miasta niezwykłym nadprzyrodzonym zjawiskom oraz Opatrzności Bożej. Papież Innocenty XI, forsując za pośrednictwem inicjatyw na polu medalierstwa przekaz bliski cesarskiemu, chciał najpewniej podkreślić, że sam aktywnie wspierał wysiłki militarne sprzymierzonych, nie tylko wysyłając pieniądze przeznaczone na formowanie kolejnych oddziałów, lecz również modląc się o rychłe pokonanie Turków.

\section{PODSUMOWANIE}

Medale zwycięstwa wiedeńskiego miały spełniać jeden zasadniczy cel propagandowy - sprostać oczekiwaniom fundatora i zarazem zleceniodawcy medalu ${ }^{29}$. Leopold I, w kluczowym momencie odsieczy przebywający poza Wiedniem, pragnął wykazać, że najważniejsze w zmaganiach z Turkami było poświęcenie żołnierza austriackiego oraz opieka opatrzności Bożej czuwającej w trudnych chwilach nad miastem i jego mieszkańcami. Przykładowo można wymienić awers medalu niezidentyfikowanego medaliera z 1683 roku. Nad panoramą Wiednia, bronionego przez nacierającą na Turków kawalerię cesarską, unosi się dwugłowy orzeł austriacki z wiązką piorunów w pazurach. Innocenty XI zaś kazał uwypuklać własne zabiegi zmierzające do unicestwienia wroga poprzez wsparcie finansowe (dotacje

${ }^{29}$ Magdalena Górska uważa, że ważnym impulsem dla ożywienia królewskiej inicjatywy na polu medalierstwa, wkrótce po 12 września 1683 roku, był przekaz propagowany za pośrednictwem medalierskiego krążka przez twórców działających na zlecenie dworu wiedeńskiego. Przekaz powyższy umniejszał zasługi Jana III Sobieskiego, wyolbrzymiał zaś zabiegi dyplomatyczne Leopolda I Habsburga w trakcie oblężenia Wiednia, por. Górska 2013, s. 88. 
papieskie) oraz modlitewne. W sposób najbardziej przemawiający upamiętniono zaangażowanie głowy Kościoła katolickiego na rewersie medalu autorstwa Giovanniego Hameraniego z 1683 roku, w treści inskrypcji ujętej w wieniec z liści palmowych: DEXTERA TVA DOMINE PERCUSSIT INIMICVM. Odpowiednio dobrana kompozycja artystyczna, składająca się z określonego repertuaru symboli, personifikacji i atrybutów, miała jedynie ułatwiać dotarcie do odbiorcy i zapewniać wpływ na jego osobiste jednostkowe decyzje.

Mimo że podczas kwerendy naukowej nie udało się odnaleźć dzieł sztuki wykorzystanych ponad wszelką wątpliwość przez medalierów podczas tworzenia medali, zachował się do naszych czasów szereg obiektów reprezentujących podobną tematykę i powstałych w podobnym okresie. I tak, graficzne widoki Wiednia, analogiczne jak w przypadku pracy Romeyna de Hooghe wykonanej w 1683 roku, bez wątpienia stanowiły punkt wyjścia dla artystów przenoszących na medalowy krążek wygląd fortyfikacji wiedeńskich czy też miniatury najważniejszych budowli, takich jak katedra św. Szczepana. Jak można było się przekonać, analizując materiał medalierski z czasów batalii wiedeńskiej, niejednokrotnie fikcja mieszała się $\mathrm{w}$ nim z rzeczywistością.

Pomocne dla artystów pragnących wykazać klęskę turecką niejednokrotnie okazywały się wcześniejsze medale zawierające wyobrażenia zaczerpnięte bezpośrednio z kompendiów emblematycznych. Dobrym przykładem takiej właśnie koncepcji jest medal autorstwa Hermana Haffnera z 1683 roku. Awers medalu to wierne medalierskie odbicie teatru działań wojennych z 12 września 1683 roku. Rewers natomiast wykazuje podobieństwo $\mathrm{z}$ drugą stroną medalu o wartości ècusa $\mathrm{z}$ czasów Ludwika XIV z 1648 roku. Należy więc zadać pytanie, w jakim celu stosowano opisane zabiegi artystyczne. Z pewnością XVII-wieczny odbiorca nie miał kłopotów z prawidłową identyfikacją symboli, takich jak chrześcijańskie wschodzące słońce czy zachodzący muzułmański półksiężyc, zlokalizowanych powyżej fikcyjnych scen walki. Aby jednak mógł poznać rzeczywiste okoliczności i rozmiar triumfu armii sprzymierzonych nad wojskami Kara Mustafy, niezbędne okazywało się utrwalenie prawdziwego teatru działań wojennych wraz z głównymi atutami, jakimi dysponowała strona chrześcijańska, w postaci nowożytnych fortyfikacji miejskich Wiednia.

\section{SEVENTEENTH-CENTURY MEDALS AND COMMEMORATIVE NUMISMATIC PIECES DEDICATED TO THE OSMAN SIEGE OF VIENNA IN 1683 AND SOME OF ITS ASPECTS}

\section{Summary}

The author of the paper describes five works of medallic and graphic art associated with medals minted in the period of the Vienna victory. Iconographic analysis of the pieces, in the light of comparison with selected examples of other medals and graphic works, offers an insight into works of art 
which display similarities to representations on the obverses and reverses of Sobieski's medals. The author demonstrates that the medals commemorating the victory at Vienna were intended to achieve one fundamental propaganda goal-meet the expectation of the founder of the medal and the party who commissioned it. Leopold I, who in the crucial moment of the relief stayed outside Vienna, sought to demonstrate that the most important element in the clash with the Turks was the sacrifice of the Austrian soldier and the divine providence which, in a time of need, protected the city and its residents. On the other hand, Innocent XI wished to highlight his own efforts made to annihilate the enemy through financial support (papal subsidy) and prayer.

\section{Bibliografia}

Ampah C., L. 1833-1835, Numophilacii Ampachiani sectio II, Naumburg.

Augustyniak U. 2019, Polska przedmurzem chrześcijańskiej Europy, Pomocnik Historyczny. Jan Król Sobieski - monarcha Sarmatów, 6, s. 18-25.

Barnett M. 1998, Götter und Mythen des alten Ägypten, Gondrom-Bindlach.

Bartynowski T. (b. d. w.), Teki Bartynowskiego: Medale z czasów Jana III (b. m. w.).

Berger D. 2004, Thomas von Aquins „Summa theologiae”, Darmstadt.

Białostocki J. 1962, Zbiory Muzeum Narodowego w Warszawie: informator, oprac. J. Białostocki, Warszawa.

Börner L. 1997, Die italienischen Medaillen der Renaissance und des Barock (1450 bis 1750), Berliner Numismatische Forschungen, 5, Berlin, 25, s. 1-458.

Broucek P., Leitsch W., Vocelka K., Wimmer J., Wójcik Z. 1983, Zwycięstwo pod Wiedniem 1683, Warszawa.

Chevalier J., Gheerbrant A. 1996, A dictionary of symbols, London.

Chowaniec Cz. 1933, Sobieski. Roi de Pologne d’aprés les estampes de l'epoque, Paris.

Chwała i sława Jana III w sztuce i literaturze. Katalog wystawy jubileuszowej z okazji trzechsetlecia odsieczy wiedeńskiej 1983, red. W. Fijałkowski i J. Mieleszko (red.), Warszawa.

Chynczewska-Hennel T. 2011, Zagrożenie tureckie w Europie - Jan III Sobieski a stolica apostolska, [w:] T. Chynczewska-Hennel (red.), Odsiecz wiedeńska. Materiały z Konferencji „Dzieje i tradycja odsieczy wiedeńskiej Jana III Sobieskiego”, 11 września 2008 roku, Warszawa, s. 49-57.

Czołowski A. 1930, Ikonografia wojenna Jana III, Przegląd Historyczno-Wojskowy, II, 2, s. 265-266)

Die erste Türkenbelagerung. Historisches Museum der Stadt Wien. 1980, red. R. Waissenberger, G. Düriegl, Wien.

Die Türken vor Wien. Europa und die Entscheidung an der Donau 1683. Katalog. 1983, red. R. Waissenberger, G. Düriegl, Wien.

Düriegl G. 1981, Wien 1683. Die zweite Türken-belagerung, Wien-Köln-Graz.

Górska M., Milewska-Waźbińska B. 2010, W teatrze życia i sławy Jana III Sobieskiego, czyli widowisko wilanowskie, Warszawa.

Górska M. 2013, Medalierski wizerunek Jana III Sobieskiego [w:] D. Walawender-Musz (red.), Primus inter pares. Pierwszy wśród równych, czyli opowieść o królu Janie III, Warszawa, s. 66-90.

Górska M. 2017, Zbawca Europy. O graficznych tezach gloryfikujących Jana III Sobieskiego, Warszawa.

Gustave B. 1955, Święty Augustyn, człowiek i dzieło, Warszawa.

Hess A. 1881-1883, Verzeichniss verkäuflicher Münzen aus der fürstlich Montenuovo'schen Münzsammlung, Frankfurt am Main. 
Hieronimus R. 1989, America’s Secret Destiny, Rochester.

Hirsch A. 1883, Die Medaillen auf den Entsatz Wiens 1683, Troppau.

Horn Ch. 1997, Augustinus. De civitate dei. Klassiker Auslegen, 11, Berlin.

Hutten-Czapski E. 1871-1916, Catalogue de la collection des médailles et monnaies polonaises du comte E. Hutten-Czapski, I-V, St. Petersbourg-Cracovie.

Jaćov M. 2003, Europa i Osmanie w okresie Lig Swiętych. Polska między Wschodem i Zachodem, Kraków.

Kamiński Cz., Kowalczyk W. 1969, Medale i medaliony polskie i związane z Polską. Katalog wystawy, Warszawa.

Karger W. 1933, Wystawa ku czci Sobieskiego w Cieszynie (3 grudzień 16 - grudzień 1933), Cieszyn-Katowice.

Katalog der historischen Ausstellung der Stadt 1883, Wien.

Katalog wystawy jubileuszowej zabytków z czasów króla Stefana i Jana III w czterechsetlecie urodzin Stefana Batorego i dwieście pięćdziesięciolecie odsieczy wiedeńskiej. Muzeum Wojska Polskiego. Muzeum Narodowe 1933, Warszawa.

Kołodziejczyk D. 2019, Imperium Osmańskie u bram, Pomocnik Historyczny. Jan Król Sobieski monarcha Sarmatów, 6, s. 37-45.

Kossarzecki K. 2019, Majątek rodzinny, Pomocnik Historyczny. Jan Król Sobieski - monarcha Sarmatów, 6, s. 67-79.

Landwehr J. 1973, Romeyn de Hooghe the etcher contemporary portrayal of Europe 1662-1707. Leiden.

Lincoln W. 1898, A decriptive catalogue of papal medals, London.

Łoski J. 2019, Jan Sobieski i jego rodzina, towarzysze broni i współczesne zabytki, Oświęcim.

Manthey J. 1956, Le bienheureux Innocent XI et La Pologne "Boulevard de la Chrétienté" sur les medailles commemoratives: de "Dextera tua Domine percussit inimicum" (1683) à "Pax fundata cum Moschis" (1686), red. J. Gawlina, Roma.

McGinn B. 2014, Thomas Aquinas's Summa theologiae: A Biography, Princeton, New Jersey.

Muntoni F. 1972-1973, Le Monete dei Papi, 1-4, Roma.

Nagielski M. 2019, Rosnąca potęga sąsiadów, Pomocnik Historyczny. Jan Król Sobieski - monarcha Sarmatów, 6, s. 6-15.

Odsiecz wiedeńska. Wystawa jubileuszowa w Zamku Królewskim na Wawelu w trzechsetlecie bitwy 1990, red. A. Franaszek, K. Kuczman, Kraków.

Polkowski I. 1884a, Monety i medale, sztychy, rękopisy, dokumenty i druki na wystawie pamiątek Sobieskiego, Kraków.

Ratzinger J. 1954, Volk und Haus Gottes in Augustins Lehre von der Kirche, Dissertation, München.

Rokita J. 2014, Funkcje propagandowe medali upamiętniających Odsiecz Wiedeńską i zawiązanie Świętej Ligii z lat 1683-1684 na tle współczesnych im źródeł historycznych, Biuletyn Numizmatyczny 1 , s. 23-48.

Rokita J. 2015a, Medal Martina Brunnera upamiętniający zawiązanie się Świętej Ligii przeciwko Turcji, wybity w 1684 roku, Biuletyn Numizmatyczny 1, s. 21-28.

Rokita J. 2015b, Medal upamiętniający przystąpienie Państwa Moskiewskiego do grona Państw-Sygnatariuszy Świętej Ligii, Biuletyn Numizmatyczny 3, s. 185-192.

Rokita J. 2015c, Medal upamiętniający Odsiecz Wiedeńską i oswobodzenie Ostrzyhomia spod okupacji tureckiej. Uwagi ikonograficzne, Biuletyn Numizmatyczny, nr 4, s. 285-298. 
Rokita J. 2015d, Medal upamiętniający zwycięstwo pod murami Wiednia (12 września 1683 roku) z wyobrażeniem dwóch: orłów polskiego i austriackiego, autorstwa Jana Höhna mł. Uwagi ikonograficzne, Studia Historyczne LVIII, nr 4, s. 459-482.

Rokita J. 2016a, W sprawie ikonografii medalu Jana Höna mł. z 1684 roku upamiętniającego zawarcie Świętej Ligii, Biuletyn Numizmatyczny 2, s. 103-112.

Rokita J. 2016b, Medale upamiętniające zwycięstwo odniesione pod Wiedniem na równi z zaćmieniem księżyca, wykonane w 1683 roku. Uwagi ikonograficzne, Piotrkowskie Zeszyty Historyczne. 17, s. 9-37.

Rokita J. 2016c, Medal na pamiątkę wręczenia papieżowi Innocentemu XI sztandarów tureckich zdobytych pod Parkanami, autorstwa Giovanniego Martino Hameraniego z 1684 roku. Uwagi ikonograficzne, Folia Historica Cracoviensia 22, s. 359-372.

Rokita J. 2017, Uwagi o medalu Johanna Neidhardta upamiętniającym zwycięstwo pod Wiedniem z roku 1683. Uwagi ikonograficzne, Almanach Historyczny XIX, s. 49-66.

Rokita J. 2018, Tematyka mitologiczna na medalu gloryfikującym postawę Jana III Sobieskiego pod Wiedniem (12 września 1683 roku). Uwagi ikonograficzne (Część pierwsza), Seminare 39, 2, s. $149-161$.

Rokita J. 2019, Tematyka mitologiczna na medalu gloryfikującym postawę Jana III Sobieskiego pod Wiedniem (12 września 1683 roku). Uwagi ikonograficzne (Część druga), Seminare 40, 1, s. 161-174..

Ruszczycówna J. 1982, Ikonografia Jana III Sobieskiego. Wybrane zagadnienia, Rocznik Muzeum Narodowego w Warszawie, \XXVI, s. 209-307.

Rzeczpospolita w dobie Jana III. Katalog wystawy Zamku Królewskiego, Archiwum Głównego Akt Dawnych i Biblioteki Narodowej 1983, red. E. Suchodolska, A. Gieysztor, Warszawa.

Stahr M. 2008, Medale polskie i z Polską związane od XVI do XVIII wieku [katalog zbiorów Muzeum Narodowego w Poznaniu], Poznań.

Stoye J. 2009, Oblężenie Wiednia, Kraków.

Sturminger W. 1951, Die Kundsschafter zur Zeit der zweiten Türkenbelagerung Wiens im Jahre 1683, Festschrift zur Feier des zweihunderjähringen Bestandes des Haus-, Hof- und Staatatschivs 1-2, Wien, s. 349-369.

Tervarent G. 1958, Attributs et symboles dans l'art profane 1450-1600: dictionnaire d'un langage perdu, Geneve.

Treiderowa A. 1960, Tematyka polska w twórczości Romeyna de Hooghe’a. Rocznik Biblioteki PAN w Krakowie VI, s. 5-47.

Tron pamiątek ku czci „Najjaśniejszego, Niezwyciężonego Jana Sobieskiego Króla Polskiego” w trzechsetlecie śmierci 1696-1996. 1996, red. J. Mieleszko, Warszawa.

Ursyn-Niemcewicz J. 1840, Zbiór Pamiętników Historycznych o dawnej Polszcze, Lipsk.

Venimus, vidimus, Deus vicit. Wiktoria wiedeńska 1683 roku w relacjach i dokumentach z epoki 1984, oprac. M. Nagielski, wstęp T. Wasilewski, Warszawa.

Widacka H. 2010, Lew Lechistanu. Jan III Sobieski w grafice, Warszawa. 